\title{
Agronomic Management and Rice Varieties Controlling Cd Bioaccumulation in Rice
}

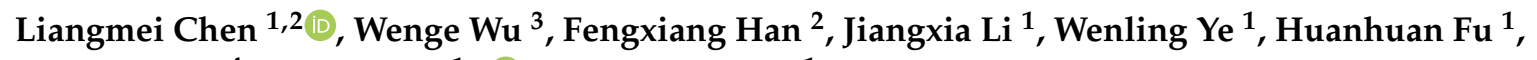 \\ Yonghua Yan ${ }^{4}$, Youhua Ma ${ }^{1, *}$ and Qiang Wang ${ }^{1, *}$ \\ 1 College of Resources and Environmental Sciences, Anhui Agriculture University, Hefei 230001, China \\ 2 Department of Chemistry and Biochemistry, Jackson State University, Jackson, MS 39056, USA \\ 3 Rice Research Institute, Anhui Academy of Agricultural Sciences, Hefei 230031, China \\ 4 Department of Math, Jackson State University, Jackson, MS 39056, USA \\ * Correspondence: yhma@ahau.edu.cn (Y.M.); 28104@ahau.edu.cn (Q.W.)
}

Received: 12 April 2019; Accepted: 2 July 2019; Published: 4 July 2019

\begin{abstract}
Selection of rice varieties and application of amendments are effective measures to ensure food safety. Here we report that in the non-Cd area, the grain quality of all rice varieties met the Chinese National Grain Safety Standards (CNGSS). In the high-Cd area, rice varieties showed significant different bioaccumulation of $\mathrm{Cd}$ with lower rice yields than those in non-Cd area with the average decrease of $31.1 \%$. There was a negative correlation between grain $\mathrm{Cd}$ content and yields. A total of 19 rice varieties were selected as low $\mathrm{Cd}$ accumulating rice varieties and their $\mathrm{Cd}$ content met CNGSS in the low-Cd area. Six of them met CNGSS in the high-Cd area. The application of amendments significantly reduced Cd content in rice grains by $1.0-84.7 \%$ with an average of $52.6 \%$ and 13 of varieties met CNGSS. The amendments reduced available $\mathrm{Cd}$ content in soils by $1.1-75.8 \%$ but had no significant effects on rice yields. Therefore, the current study implied that proper agronomic management with selection of rice varieties and soil amendments was essential in controlling $\mathrm{Cd}$ accumulation in rice grains.
\end{abstract}

Keywords: rice; varieties; Cd; biological organic fertilizers; lime; porous ceramic nanomaterials

\section{Introduction}

Rice is one of the main food crops in the world. However, it is capable of absorbing toxic heavy metals such as cadmium. Cadmium can be readily accumulated in rice, resulting in Cd content in grains exceeding the human consumption standard limits. This became an increasingly serious food safety concern, especially in developing countries with fast economy development [1,2]. High Cd concentration in plants retards their growth and development, producing poor grains and low yields. Further enrichment in food chain eventually causes serious $\mathrm{Cd}$ threat to human and animal health. To produce high-yield rice with superior quality, it is necessary to take a series of comprehensive management and agronomic practices in reducing rice $\mathrm{Cd}$ content.

Screening low $\mathrm{Cd}$ accumulating varieties, agronomic practices as well as remediation techniques are useful methods to reduce $\mathrm{Cd}$ accumulation in rice plants, improve rice quality, and prevent $\mathrm{Cd}$ from entering food chains. Low accumulating varieties were utilized successfully in bread wheats, sunflower, and other crops [3,4]. Previous studies identified some genetic variation in heavy metal uptake and their deposits in grains. Liu et al. observed that rice varieties varied greatly both in absorption of $\mathrm{Cd}$ and in responses to $\mathrm{Cd}$ [5]. Shi et al. tested 110 rice varieties in fields and observed that $\mathrm{Cd}$ concentrations of super rice varieties were 14 times that of hybrid rice [6]. Yu et al. also proved that there were significant differences among rice varieties and 30 out of 43 cultivars were tested as relatively safe varieties regarding $\mathrm{Cd}$ accumulation [7]. Liu et al. found that $\mathrm{Cd}$ concentrations 
ranged from 0.22 to $2.86 \mathrm{mg} \mathrm{kg}^{-1}$ in brown rice among cultivating 52 rice varieties. ${ }^{5}$ It was shown to be feasible to screen rice varieties with low accumulation of cadmium as the means to control heavy metal bioaccumulation [8,9]. Furthermore, previous studies showed that the application of biological organic fertilizers not only reduced contents of soil available heavy metals, but also improved soil fertility leading to high crop economic yields $[10,11]$. Lime reduced diethylene triamine pentacetic acid (DTPA) extracted heavy metal content through raising soil $\mathrm{pH}$ [12]. SAMMNS porous ceramics are a new type nanocomposite material with unique highly self-assembly and high density functional single molecules and controllable ordered high porosity. The materials had a large, selective adsorption capacity, and long lifetime [13]. Combining these materials not only reduced the effective cadmium content in the soil, but also improved the soil environment. To effectively prevent $\mathrm{Cd}$ accumulation in foods, the best strategy is to combine low $\mathrm{Cd}$ rice varieties with soil remediation technology $[14,15]$.

The objectives of this study were to investigate the effects of rice varieties and agronomic practices on controlling rice $\mathrm{Cd}$ accumulations. We proposed the hypothesis that coupling low $\mathrm{Cd}$ accumulating rice varieties with soil amendments significantly reduced $\mathrm{Cd}$ accumulation in rice grains. A comprehensive strategy for growing rice on Cd contaminated soil was developed.

\section{Material and Methods}

\subsection{Description of Field Experimental Plots}

\subsubsection{Methods for Soil and Plant Sampling}

The diagonal sampling method was used to collect soil and plant samples. Three points were selected along diagonally across the rectangular test area as sampling points. Soil was taken from depths of $1-5 \mathrm{~cm}$ and $5-15 \mathrm{~cm}$, and mixed well. The plant sample was collected on the aerial part and the sampling point was in one-to-one correspondence with the sampling point of the soil sample. At the same time sufficient sample sizes from each point were ensured. Then the composite plant samples of the three points were mixed.

\subsubsection{Test Area Background}

We defined a low cadmium region with a soil contaminant content of 1-2 times the screening value $\left(0.3 \mathrm{mg} \cdot \mathrm{kg}^{-1}\right)$ of GB15618-2018, and a high cadmium region with a content exceeding the risk intervention values $\left(1.5 \mathrm{mg} \cdot \mathrm{kg}^{-1}\right)$ of GB15618-2018 with the single pollution index evaluation method.

The experiments were conducted in a mine area in Tongling, Anhui Province, China. The farmlands were classified into low-Cd area and non-Cd area. Soil Cd background content in the area was 0.196 mg.kg-1 (Geological Survey of the Ministry of Environmental Protection) [16]. The soil was red loam. Some selected soil physical and chemical properties, and Cd background levels were described in Table 1.

Table 1. Selected soil physicochemical properties.

\begin{tabular}{|c|c|c|c|c|c|c|c|c|}
\hline $\begin{array}{l}\text { Degree of } \\
\text { Pollution }\end{array}$ & Soil Available Cd & $\begin{array}{c}\text { Soil } \\
\text { Total Cd }\end{array}$ & $\mathrm{pH}$ & CEC & $\begin{array}{c}\text { Alkaline } \\
\text { Hydrolytic } \\
\text { Nitrogen }\end{array}$ & $\begin{array}{c}\text { Soil } \\
\text { Available } \\
\text { Phosphorus }\end{array}$ & $\begin{array}{c}\text { Rapidly } \\
\text { Available } \\
\text { Potassium }\end{array}$ & $\begin{array}{l}\text { Organic } \\
\text { Matters }\end{array}$ \\
\hline & $\mathrm{mg} \cdot \mathrm{kg}^{-1}$ & $\mathrm{mg} \cdot \mathrm{kg}^{-1}$ & & $\mathrm{cmol} \cdot \mathrm{kg}^{-1}$ & $\mathrm{mg} \cdot \mathrm{kg}^{-1}$ & $\mathrm{mg} \cdot \mathrm{kg}^{-1}$ & $\mathrm{mg} \cdot \mathrm{kg}^{-1}$ & $\mathrm{~g} \cdot \mathrm{kg}^{-1}$ \\
\hline Non-Cd area & 0.172 & 0.261 & 6.51 & 14.79 & 123.57 & 19.78 & 81.25 & 25.71 \\
\hline Low-Cd area & 0.361 & 0.389 & 5.93 & 13.56 & 133.35 & 19.25 & 136.67 & 22.47 \\
\hline High-Cd area & 1.36 & 1.83 & 5.03 & 12.95 & 120.27 & 19.15 & 74.32 & 23.66 \\
\hline
\end{tabular}

\subsection{Rice Varieties and Stabilization Agents}

\subsubsection{Rice Varieties Used for the Screening Test}

For the screening test, the following 45 rice varieties were used. 
A. Conventional Japonica Rice Cultivars (19 varieties):

a) The medium maturity medium Japonica variety (3) including: Xudao5, Xinkedao21, Xudao7;

b) The late maturity medium Japonica varieties (5): Wandao 68, Zhendao 14, Ningjing 4, Yangyujing2, Nanjing49;

c) The early maturity late Japonica varieties (8) including: Ningjing 2, Zhendao 11, Wandao 94, Jiahua 1, Wuyunjing 23, Wuyunjing 29, Yangjing 4227, Zhendao 18;

d) The Mid maturity late Japonica varieties (3): Nanjing 94140, Xiushui 63, Xiushui 134;

B. The Hybrid Japonica rice varieties (3):

a) Medium japonica variety: III you 98;

b) Late japonica varieties: Yongyou 8, Jiayou 2.

C. Conventional Indian rice varieties (5):

Teqing, IR36, Nanjing 11, Zhenzhuai, Guichao 2.

D. Hybrid Indica rice varieties (18):

a) Two-line hybrid Medium Indica rice (15): Xinliangyou 6, Xinliangyouxiang 4, Xinliangyou 106, Feng Liangyou 1, Feng liang you xiang 1, Hui Liangyouc898, Liangyouxin 90, Guangliangyou 1128, Liangyou 6206, Liangyou 378, Liangyou 766, Liangyou 8106, ZhunLiangyou 608, Shenliangyou 1813, Xiangliangyou 2

b) Three-line hybrid medium Indica rice varieties (3): IIyou 293, F you 498, II you 838

\subsubsection{Low Cd Rice Varieties Used for Remediation}

For testing the effects of low $\mathrm{Cd}$ rice varieties in combination with the mixture of limes, organic fertilizers and SAMMNS porous ceramics nanomaterials on rice $\mathrm{Cd}$ contents. The following rice varieties were used: Ningjing 4, Zhendao 11, Xiushui 63, Xudao 5, Xudao 7, Ningjing 5, Jiayou 2, Zhendao 14, Wandao 68, Yangjing 4227, Zhendao 18, Nanjing 11, Fengliangyouxiang 1, Liangyou 6206, Xinliangyou 106, Xinkedao 21, Teqing, Xinliangyou 917, Xinliangyou 1671, Liangyou 766, Zhenzhuai, Liangyou 8106 which were selected from studied conducted during first two years.

A mixture of lime, organic fertilizers, and SAMMNS porous ceramics was used as the soil stabilization agents.

\subsection{Rice Variety Screening Experiment Design}

Forty-five rice varieties were grown from 2014-2015 for two consecutive years in a high-Cd area and a non- $\mathrm{Cd}$ area. The high-Cd area and non- $\mathrm{Cd}$ area were two rectangular areas ( $\mathrm{L} \times \mathrm{W}: 120 \mathrm{~m} \times 30 \mathrm{~m})$ separated by cement concrete, and each area was designed with split-plot experiment design. The distance between two adjacent varieties was $50 \mathrm{~cm}$, and the area of each variety was $6 \mathrm{~m}^{2}(2 \times 3 \mathrm{~m})$. Each variety had three replicates with the total 135 plots. Each of the 45 varieties in each of the three replicates was randomly distributed in a grid $(5 \times 9)$. The three repeats are arranged side by side with the middle separated by cement concrete. Rice plants were randomly planted at a space of $20 \mathrm{~cm}$ between rows. Direct seeding rate of conventional rice varieties was $50 \mathrm{~kg} \cdot \mathrm{hm}^{-2}$ and that of hybrid rice varieties was $40 \mathrm{~kg} \cdot \mathrm{hm}^{-2}$. Fertilizers included fully-fermented manure applied at $14990 \mathrm{~kg} \cdot \mathrm{hm}^{-2} \mathrm{and}^{-}$ commercial organic fertilizer at a rate of $1200-1500 \mathrm{~kg} \cdot \mathrm{hm}^{-2}$. nitrogen fertilizer rate was $225 \mathrm{~kg} \cdot \mathrm{hm}^{-2}$ for the Japonica rice and $210 \mathrm{~kg} \cdot \mathrm{hm}^{-2}$ for Indica rice varieties. Phosphate fertilizer $\left(\mathrm{P}_{2} \mathrm{O}_{5}\right)$ was used at $60 \mathrm{~kg} \cdot \mathrm{hm}^{-2}$ and potash fertilizer $\left(\mathrm{K}_{2} \mathrm{O}\right)$ at $120 \mathrm{~kg} \cdot \mathrm{hm}^{-2}$.

There were four stages for fertilization. Therefore, we divided all the nitrogen fertilizer and potash fertilizer that the rice needed into four scale parts. Organic and potash fertilizers were applied as base fertilizers containing $40 \%$ nitrogen fertilizer and $60 \%$ potash fertilizer and $1 \mathrm{~kg} \mathrm{hm}^{-2} \mathrm{ZnSO}_{4}$. Additional 
fertilizers were used in the rice tillering stage ( $15 \%$ nitrogen fertilizer), panicle ( $35 \%$ nitrogen fertilizer and $40 \%$ potash fertilizer), and grain stages (10\% nitrogen fertilizer). Seeds were sown in May and crops were harvested at the end of September. Plants and soil samples were collected to analyze Cd contents in grains and soil. Rice yield data were collected after samples. All the rice grain of each variety were collected and weighed separately for yield measurement.

2.4. Soil Remediation Experiments with a Combination of Low Cd Accumulating Rice Variety and Applications of Stabilization Agents

In 2016, 19 low-Cd-accumulating rice varieties selected from the previous two-year screening experiment were planted in the high-Cd and low-Cd areas. Each rice variety plot was $334 \mathrm{~m}^{2}$. The first half of the plot was applied with the mixture of lime $\left(900 \mathrm{~kg} \cdot \mathrm{hm}^{-2}\right)$-biological organic fertilizer $\left(3000 \mathrm{~kg} \cdot \mathrm{hm}^{-2}\right)$ and SAMMNS porous ceramics $\left(3000 \mathrm{~kg} \cdot \mathrm{hm}^{-2}\right)$ and the other half was blank. The amendment rate values determined by previous soil amendment repair experiments we did before. The method of incorporating the amendments into the soil was as follows. Firstly, before transplanting rice, we apply the required amount of lime to the planting area of each variety, and then plow the soil to evenly stir the lime into the farm soil. Then the bio-organic fertilizer is applied one week after the lime application, and the application method and the tillage method are the same as the lime. Finally, the porous ceramic nanomaterial is applied before the irrigation of the farmland, and the application method and the tillage method are the same as the lime, and then the farmland is irrigated. The direct seeding rate of conventional rice varieties was $50 \mathrm{~kg} \cdot \mathrm{hm}^{-2}$ and that of hybrid rice varieties was $40 \mathrm{~kg} \cdot \mathrm{hm}^{-2}$ with a planting distance of $20 \mathrm{~cm}$. Fertilizer application followed the same scheme of the previous two-year screening experiment.

Biological organic fertilizer was purchased from Beijing Long Age AMMS biological technology Co., Ltd. The colony-forming unit (CFU) of the fertilizer was $\geq 0.20 \times 10^{\wedge} 8 \cdot \mathrm{g}^{-1}$ and the organic matter was $20.0 \%$ or more. The effective bacterial species were Bacillus subtilis and Paenibacillus mucilaginosus. The modified porous nanoceramic material from Anhui GFTEM Environmental Protection Science and Technology Co., Ltd. was a new high self-assembled, densely functional single molecule, ordered and controlled porous nanocomposite. This material had functional groups introduced on the pore surface of ceramic nanomaterials (silicon or ceramic as the carrier). It combined submicroporous ceramic material preparation technology and single molecule self-assembly technology. The submicroporous ceramic material was a novel material with a high pore size controllable specific surface area and its pore size can be controlled from $5 \mathrm{~nm}$ to $2000 \mathrm{~nm}$ with the specific surface area of $900 \mathrm{~m}^{2} \cdot \mathrm{g}^{-1}$, which provides the high adsorption rate necessary for chemical separation. Single-molecule self-assembly technology formed organic layer molecules with functional groups to generate monolayer bonds on the surface of the ceramic in an orderly and high-density manner. This provided submicroporous ceramics with excellent molecular recognition capabilities to effectively remove heavy metals or other target contaminants.

\subsection{Analytical Methods}

$\mathrm{Cd}$ content in rice grains was analyzed using the GB/T5009.15-2003 method. About $0.5 \mathrm{~g}$ brown rice samples were digested with $10 \mathrm{~mL} \mathrm{HNO}_{3}$ in a CEM MARS6. The contents of the elements were measured with graphite furnace atomic absorption spectrophotometry (Jena Z700P atomic absorption spectrophotometer, Gena, Germany).

Available Cd content in soil was analyzed with GB/T 23739-2009 method. About 5.0 g soil sample was shaken for $2 \mathrm{~h}$ with $25 \mathrm{~mL}$ diethylene triamine pentacetic acid on a horizontal reciprocating oscillator. Mixed solution was filtered through filter paper. $\mathrm{Cd}$ in the filtrate solutions was measured with graphite furnace atomic absorption spectrophotometry.

Soil $\mathrm{pH}$ and nutrients contents were assayed with the Chinese national standard assay methods (pH: GB 7859-1987; N: GB 7173-1987, P: GB 7853-1987, K: GB 7856-1987; organic matter: GB 9834-1988). 


\subsection{Statistical Analyses}

Significance analyses among the treatments (P < 0.05) were conducted using SPSS19.0 (SPSS Inc., Chicago, IL, USA) and Duncan's new multiple range test. Figures and tables were completed with Origin 8.0 (Originlab, Northampton, MA, USA) and Excel 2007 (Microsoft, Redmond, WA, USA).

\section{Results}

\subsection{Cd Accumulation in Rice Varieties}

Cd contents in rice grains cultivated in 2014 and 2015 were shown in Figure 1. In the first two-year experiments, there were significant differences in grain $\mathrm{Cd}$ content among rice varieties $(P<0.05)$. In 2014 and 2015, grain Cd content of rice planted in the non-Cd area was 0.0012-0.14 mg.kg ${ }^{-1}$, which was below the national grain safety standard of $0.2 \mathrm{mg} \cdot \mathrm{kg}^{-1}$ as specified in GB2762-2012.

In 2014, the grain Cd content of Japonica rice planted in the high-Cd area was $0.05-1.05 \mathrm{mg} \cdot \mathrm{kg}^{-1}$ with an average of $0.59 \mathrm{mg} \cdot \mathrm{kg}^{-1}$ and a variance index of $51.9 \%$. Grain Cd content of the following rice varieties (Xudao 5, a medium maturity Japonica variety), Ningjing 4 (a late maturity Japonica variety), Jiayou 2 (a late Japonica variety) reached the national food safety standard. The Cd content in Indica rice grains was $0.16 \sim 1.16 \mathrm{mg} \cdot \mathrm{kg}^{-1}$ with an average of $0.69 \mathrm{mg} \cdot \mathrm{kg}^{-1}$ and a variance index of $40.6 \%$. Grain Cd content of the following rice varieties: Guichao 2, a conventional Indica variety) and Liangyou 6206 (a two-line hybrid medium Indica variety) reached the national food safety standard.

In 2015, the grain Cd content of Japonica rice produced in the high-Cd area was $0.19-1.01 \mathrm{mg} \cdot \mathrm{kg}^{-1}$ with an average of $0.56 \mathrm{mg} \cdot \mathrm{kg}^{-1}$ and a variance index of $35.8 \%$. The grain Cd content of Xudao 7 (medium maturity medium japonica variety) met the national food safety standard. The grain $\mathrm{Cd}$ content of Indica rice was $0.61-2.19 \mathrm{mg} \cdot \mathrm{kg}^{-1}$ with an average of $1.26 \mathrm{mg} \cdot \mathrm{kg}^{-1}$ and a variance index at $30.4 \%$. None of the Indica rice varieties met the national food safety standard. These results indicated that Japonica rice grain had a lower accumulation of cadmium than the Indica rice, i.e., conventional varieties had a lower accumulation of cadmium than hybrid rice.

From the above field experiments, the following 19 rice varieties had low $\mathrm{Cd}$ accumulation: Ningjing 4, Zhendao 11, Xiushui 63, Xudao 5, Xudao 7, Jiayou 2, Zhendao 14, Wandao 68, Yangjing 4227, Zhendao 18, Nanjing 11, Fengliangyouxiang 1, Liangyou 6206, Xinliangyou 106, Xinkedao 21, Teqing, Liangyou 766, Zhenzhuai, and Liangyou 8106. These varieties may be used as low $\mathrm{Cd}$ accumulating varieties in future studies. The Cd sensitive varieties included Liangyouxin 90, Huiliangyou 898, Shenliangyou 1813, Xiangliangyou 2, Guangliangyou 1128, Xinliangyouxiang 4, Ilyou 838, and II you 293. These varieties were hybrid rice.

\subsection{Yields of Rice Varieties and Their Sensitivity to $C d$}

Yields of the rice planted in the non-Cd area was significantly higher than those in the high-Cd area (Figure 2). In 2014, rice yields in the high-Cd area were $4583-8396 \mathrm{~kg} \cdot \mathrm{hm}^{-2}$ with an average of $6086 \mathrm{~kg} \cdot \mathrm{hm}^{-2}$ and a variance index at $16.7 \%$. The varieties including Huiliangyou 898, Fyou 498, Guangliangyou 1128, II you 838, Zhunliangyou 608, Xiangliangyou 2, Xinliangyou 106, Xinliangyouxiang 4, Yongyou 8, Xinliangyou 6, and Fengliangyou 1 produced relatively higher yields. 
(a) 2014

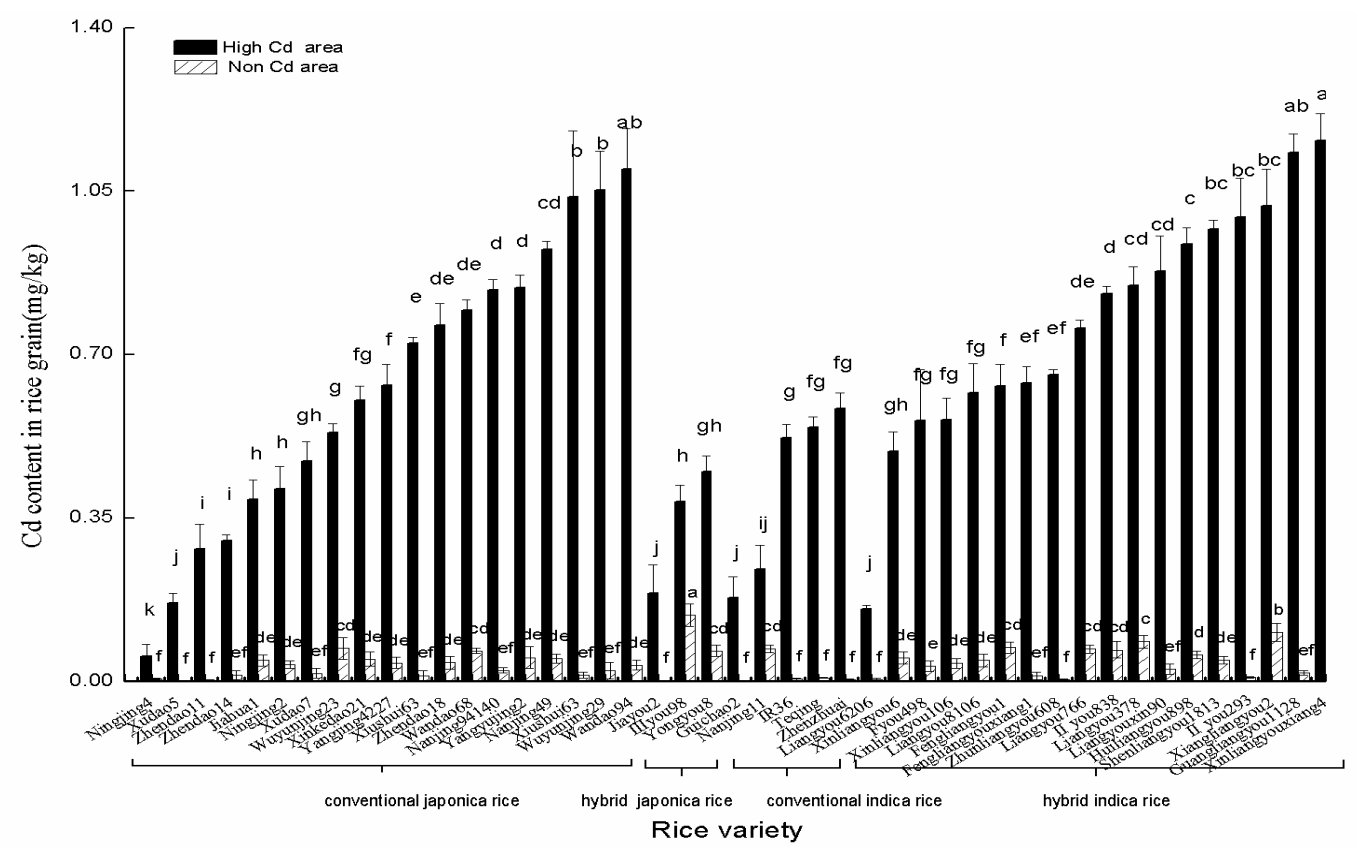

(b) 2015

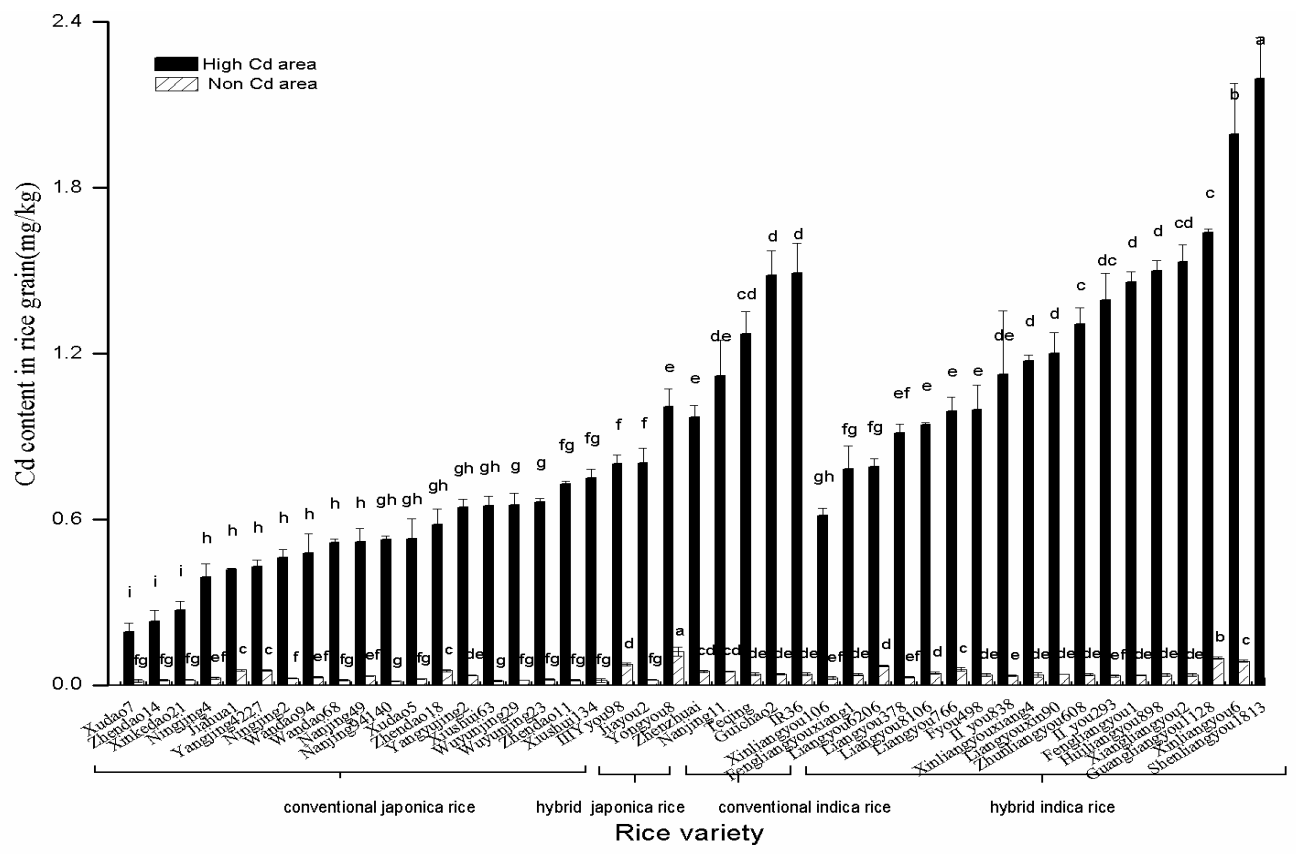

Figure 1. Cd content in rice grains in (a) 2014 rice season and (b)2015 rice season. Different letters above columns indicate significant difference among varieties at 0.05 level. 
(a) 2014

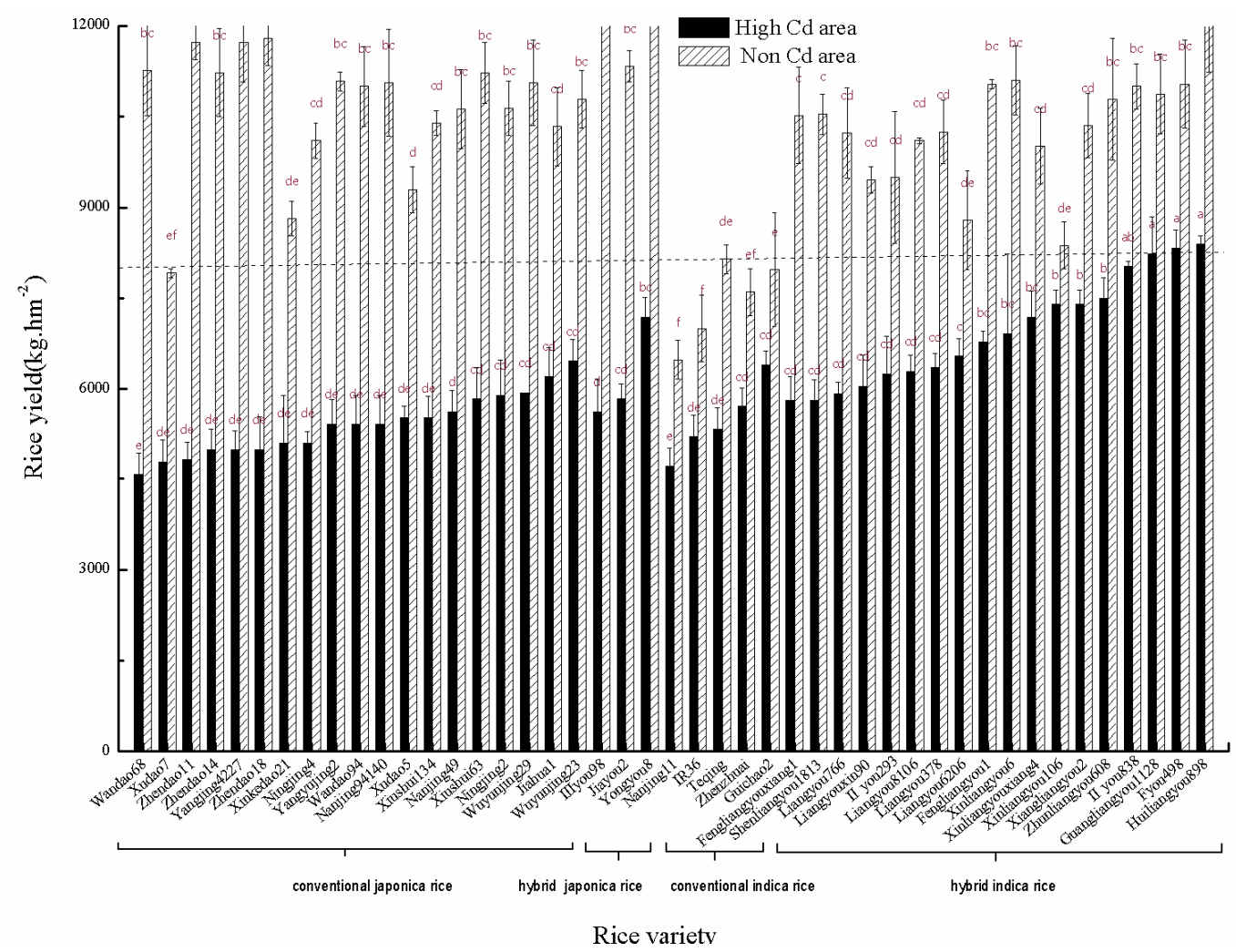

(b) 2015

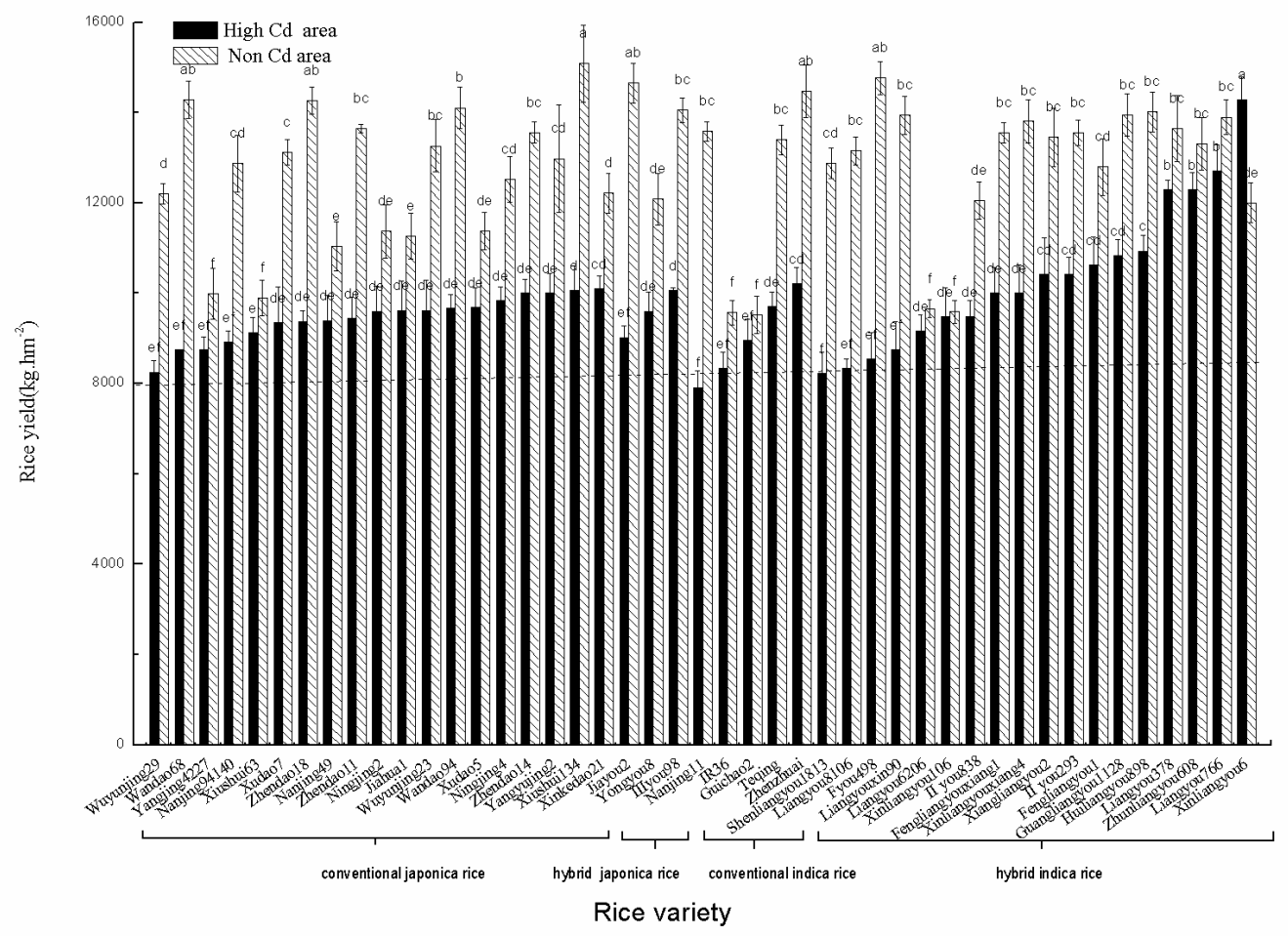

Figure 2. Rice yields in (a) 2014 rice season and (b) 2015 rice season. Different letters above columns indicate significant difference among varieties at 0.05 level. 
In the non-Cd farmland, rice yields were $6479-13042 \mathrm{~kg} \cdot \mathrm{hm}^{-2}$ with an average of $10265 \mathrm{~kg} \cdot \mathrm{hm}^{-2}$ and the variance index of $13.9 \%$. The high yield varieties included Huiliangyou 898, Yongyou 8, Xinliangyou 6, Xiushui 63, Jiayou 2, III you 98, Zhendao 18, Yangjing 4227, Zhendao 14, Zhendao 11, etc.

In 2015, rice yields in the high-Cd area were 7917-14292 $\mathrm{kg} \cdot \mathrm{hm}^{-2}$ with an average of $9782 \mathrm{~kg} \cdot \mathrm{hm}^{-2}$ and the variance index of $12.6 \%$. The high yield varieties included Xinliangyou 6, Liangyou 766, Liangyou 378, Zhunliangyou 608, Huiliangyou 898, Guangliangyou 1128, Fengliangyou 1, Xiangliangyou 2, II you 293, Zhenzhuai, Xinkedao 21, etc.

In the non-Cd area, rice yields were $9515-18089 \mathrm{~kg} \cdot \mathrm{hm}^{-2}$ with an average of $12765 \mathrm{~kg} \cdot \mathrm{hm}^{-2}$ and the variance index of $12.1 \%$. The high yield rice varieties included Zhendao 18, Jiayou 2, Zhenzhuai, Xiushui 134, Wandao 94, Wandao 68, Fyou 498, etc.

\subsection{Relationship between Rice Grain Cd Accumulation and Rice Yields}

The results showed that there was a significant negative relation between grain $\mathrm{Cd}$ content and yields. The relationship between Cd content in rice grains and rice yields in 2014 rice season is

$$
\left.y=10128.8-4074.3 e^{\left(-\frac{0.0000014}{x^{7}}\right)} \quad \text { (correlation coefficient : } 0.822\right)
$$

and the relationship between Cd content in rice grains and rice yields in the 2015 rice season is

$$
y=9679 /(1-0.295)^{*} e^{(-5.06 x)} \text { (correlation coefficient: 0.765). }
$$

These results may provide a theoretical basis for the selection of rice varieties with low cadmium accumulation and high yields. Rice yields seemed stabilized when $\mathrm{Cd}$ concentration in rice grain increased from 0 to $0.12 \mathrm{mg} \cdot \mathrm{kg}^{-1}$ in 2014 and increased from 0 to $0.11 \mathrm{mg} \cdot \mathrm{kg}^{-1}$ in 2015 . Rice yields were reduced significantly when rice grain Cd accumulation increased from 0.12 to $0.24 \mathrm{mg} \cdot \mathrm{kg}^{-1}$ in 2014 and increased from 0.11 to $0.19 \mathrm{mg} \cdot \mathrm{kg}^{-1}$ in 2015. With further increasing in Cd content in rice, the rice yields seemed changed significantly (Figure 3 ).

\subsection{Effects of Soil Amendments with a Mixture of Lime, Organic Fertilizers, and Porous Ceramics on Rice Cd Contents}

$\mathrm{Cd}$ content of the rice from $\mathrm{Cd}$ heavily contaminated, lightly contaminated, and non-contaminated farmland in 2016 were presented in Table 2.

In 2016, we cultivated low $\mathrm{Cd}$ accumulating rice varieties in the high-Cd and low-Cd areas. In the low-Cd area, rice grain $\mathrm{Cd}$ content was $0.023-0.081 \mathrm{mg} \cdot \mathrm{kg}^{-1}$, which met the national grain safety standard. Cd content of the rice planted in the low-Cd area was significantly lower than that planted in the high-Cd area. In the high-Cd area without soil amendments, rice $\mathrm{Cd}$ content was $0.11-0.81$ $\mathrm{mg} \cdot \mathrm{kg}^{-1}$ with an average of $0.33 \mathrm{mg} \cdot \mathrm{kg}^{-1}$. Cd content of rice varieties including Jiayou 2, Xudao 7, Xudao 5, Xiushui 63, Zhendao 11, and Ningjing 4 reached the national grain safety standard. In the high-Cd area, after using the mixture of lime, organic fertilizer, and porous ceramics, rice $\mathrm{Cd}$ content was reduced to $0.021-0.42 \mathrm{mg} \cdot \mathrm{kg}^{-1}$ with an average of $0.16 \mathrm{mg} \cdot \mathrm{kg}^{-1}$. The following 13 varieties rice were able to meet the national grain safety standard: Ninging 4, Zhendao 11, Xiushui 63, Xudao 5 , Xudao 7, Jiayou 2, Zhendao 14, Yangjing 4227, Zhendao 18, Xinliangyou 106, Xinkedao 21, Teqing, and Zhenzhuai. After the application of the amendment, the $\mathrm{Cd}$ content of rice grains decreased by $1.0-84.7 \%$ with an average of $52.6 \%$. More importantly, these soil amendments significantly reduced Cd content of all rice varieties except Fengliangyouxiang 4, Nanjing 11, Wandao 68, Zhendao 14, and Ningjing 4 . 
(a) 2014

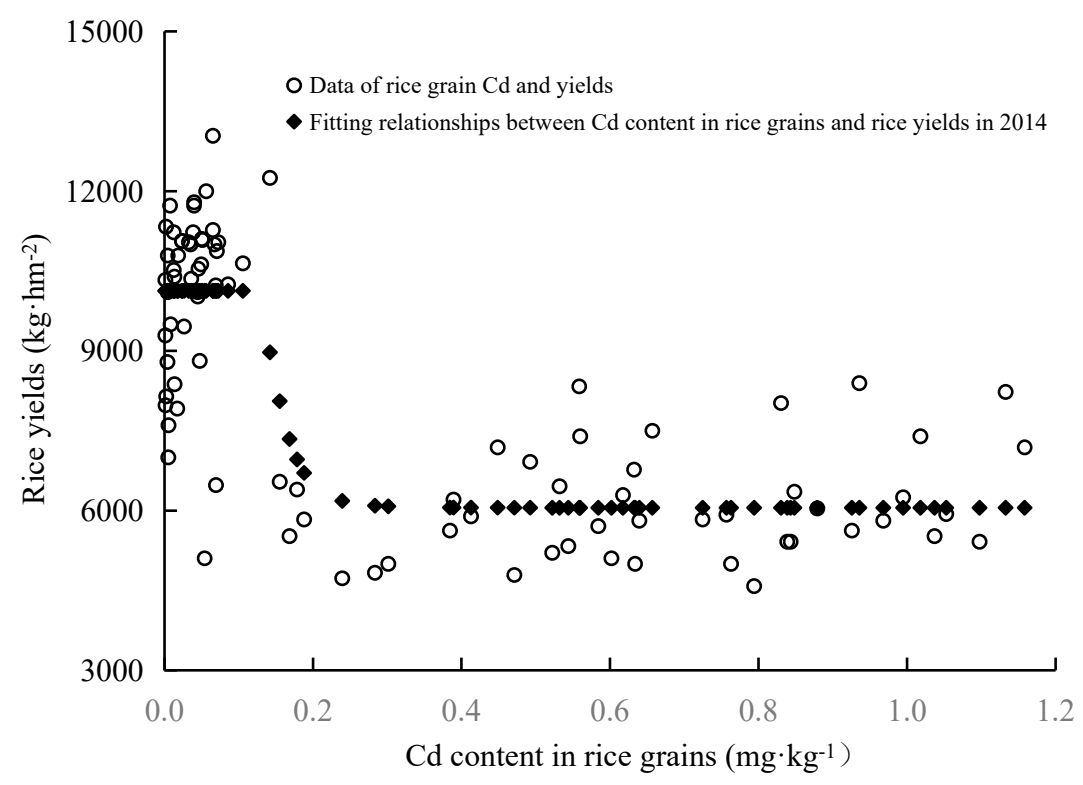

(b) 2015

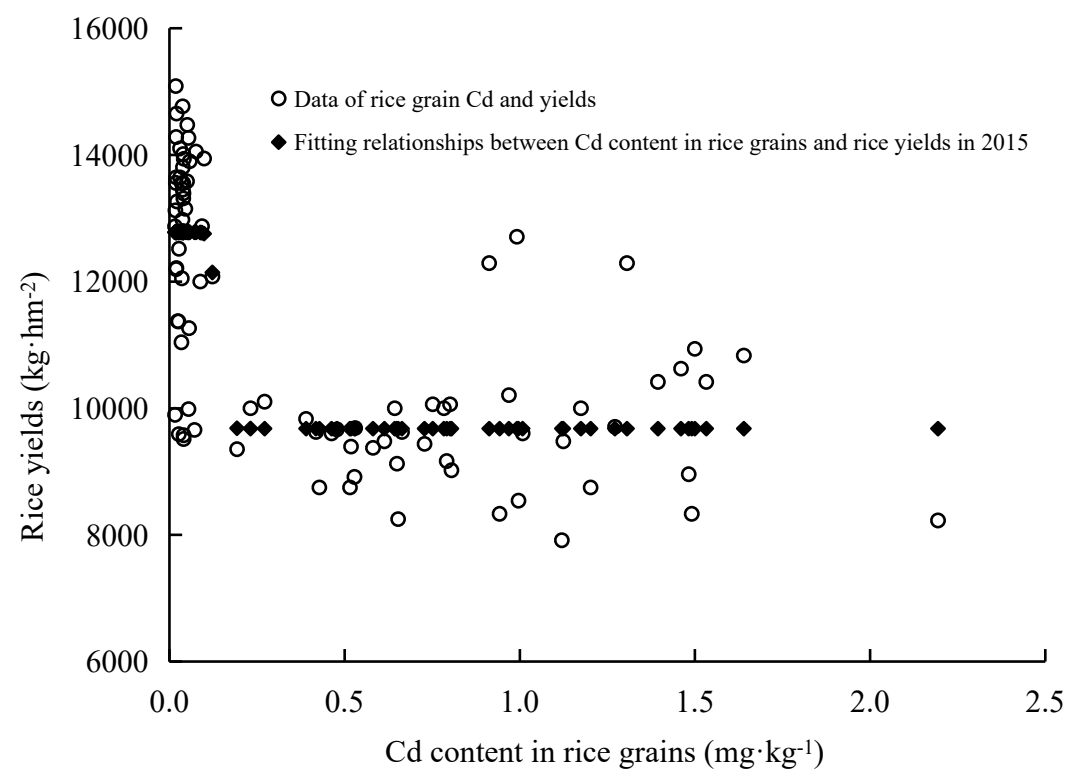

Figure 3. Relationships between Cd content in rice grains and rice yields: (a) 2014, (b) 2015. 
Table 2. Cd content in rice grains and bioavailable Cd content in soils with different treatments.

\begin{tabular}{|c|c|c|c|c|c|c|c|}
\hline \multirow{2}{*}{\multicolumn{2}{|c|}{ Rice Varieties }} & \multicolumn{2}{|c|}{ High-Cd area } & \multicolumn{2}{|c|}{$\begin{array}{l}\text { High-Cd Area + Soil } \\
\text { Amendments }\end{array}$} & \multicolumn{2}{|c|}{ Low-Cd Area } \\
\hline & & Rice Grain & bioavailable & Rice Grain & Bioavailable & Rice Grain & Bioavailable \\
\hline \multirow{8}{*}{$\begin{array}{l}\text { Indica rice } \\
\text { variety }\end{array}$} & Liangyou 8106 & $0.81 \pm 0.03 a$ & $0.96 \pm 0.06 a$ & $0.42 \pm 0.03 b$ & $0.47 \pm 0.05 b$ & $0.039 \pm 0.003 c$ & $0.38 \pm 0.03 c$ \\
\hline & Zhenzhuai & $0.56 \pm 0.03 a$ & $1.12 \pm 0.09 \mathrm{a}$ & $0.14 \pm 0.02 b$ & $0.64 \pm 0.05 b$ & & \\
\hline & Liangyou 766 & $0.56 \pm 0.06 a$ & $0.67 \pm 0.12 \mathrm{a}$ & $0.26 \pm 0.03 b$ & $0.59 \pm 0.09 a$ & $0.081 \pm 0.002 c$ & $0.41 \pm 0.02 b$ \\
\hline & Teqing & $0.53 \pm 0.08 \mathrm{a}$ & $1.32 \pm 0.08 \mathrm{a}$ & $0.18 \pm 0.01 b$ & $0.86 \pm 0.05 b$ & $0.039 \pm 0.003 c$ & $0.41 \pm 0.01 c$ \\
\hline & Xinliangyou 106 & $0.48 \pm 0.02 \mathrm{a}$ & $1.07 \pm 0.10 \mathrm{a}$ & $0.17 \pm 0.02 b$ & $0.99 \pm 0.14 \mathrm{a}$ & $0.023 \pm 0.004 c$ & $0.41 \pm 0.08 b$ \\
\hline & Liangyou 6206 & $0.38 \pm 0.05 a$ & $0.92 \pm 0.05 a$ & $0.22 \pm 0.02 b$ & $0.81 \pm 0.07 a$ & & \\
\hline & Fengliangyouxiang1 & $0.35 \pm 0.01 \mathrm{a}$ & $1.21 \pm 0.05 a$ & $0.27 \pm 0.07 \mathrm{a}$ & $1.07 \pm 0.07 b$ & $0.042 \pm 0.003 b$ & $0.34 \pm 0.03 c$ \\
\hline & Nanjing 11 & $0.29 \pm 0.04 \mathrm{a}$ & $0.60 \pm 0.04 \mathrm{a}$ & $0.23 \pm 0.02 \mathrm{a}$ & $0.57 \pm 0.04 a$ & & \\
\hline \multirow{11}{*}{$\begin{array}{l}\text { Japonica } \\
\text { rice variety }\end{array}$} & Xinkedao 21 & $0.52 \pm 0.05 a$ & $1.11 \pm 0.09 \mathrm{a}$ & $0.13 \pm 0.01 b$ & $0.73 \pm 0.07 b$ & & \\
\hline & Zhendao 18 & $0.26 \pm 0.02 \mathrm{a}$ & $1.24 \pm 0.07 a$ & $0.09 \pm 0.02 b$ & $1.22 \pm 0.09 a$ & $0.029 \pm 0.004 c$ & $0.36 \pm 0.06 \mathrm{~b}$ \\
\hline & Yangjing 4227 & $0.25 \pm 0.02 \mathrm{a}$ & $1.48 \pm 0.06 \mathrm{a}$ & $0.15 \pm 0.02 b$ & $0.85 \pm 0.09 b$ & $0.023 \pm 0.003 c$ & $0.41 \pm 0.01 \mathrm{c}$ \\
\hline & Wandao 68 & $0.24 \pm 0.04 \mathrm{a}$ & $1.25 \pm 0.05 a$ & $0.23 \pm 0.02 \mathrm{a}$ & $1.03 \pm 0.09 b$ & & \\
\hline & Zhendao 14 & $0.22 \pm 0.03 a$ & $1.01 \pm 0.13 a$ & $0.14 \pm 0.04 a$ & $0.24 \pm 0.03 b$ & & \\
\hline & Jiayou 2 & $0.17 \pm 0.03 \mathrm{a}$ & $1.11 \pm 0.09 \mathrm{a}$ & $0.11 \pm 0.01 b$ & $0.38 \pm 0.03 b$ & & \\
\hline & Xudao 7 & $0.14 \pm 0.02 \mathrm{a}$ & $1.08 \pm 0.06 a$ & $0.03 \pm 0.01 b$ & $0.62 \pm 0.03 b$ & $0.038 \pm 0.003 b$ & $0.35 \pm 0.05 c$ \\
\hline & Xudao 5 & $0.14 \pm 0.03 a$ & $0.96 \pm 0.08 \mathrm{a}$ & $0.02 \pm 0.005 b$ & $0.66 \pm 0.06 b$ & $0.045 \pm 0.002 b$ & $0.26 \pm 0.04 c$ \\
\hline & Xiushui 63 & $0.14 \pm 0.01 \mathrm{a}$ & $1.08 \pm 0.18 \mathrm{a}$ & $0.02 \pm 0.005 b$ & $0.75 \pm 0.09 b$ & $0.034 \pm 0.002 c$ & $0.41 \pm 0.04 c$ \\
\hline & Zhendao 11 & $0.12 \pm 0.02 \mathrm{a}$ & $0.60 \pm 0.08 \mathrm{a}$ & $0.05 \pm 0.004 b$ & $0.59 \pm 0.04 a$ & & \\
\hline & Ningjing 4 & $0.11 \pm 0.02 \mathrm{a}$ & $0.86 \pm 0.10 \mathrm{a}$ & $0.11 \pm 0.02 \mathrm{a}$ & $0.65 \pm 0.07 \mathrm{~b}$ & $0.060 \pm 0.003 b$ & $0.40 \pm 0.04 c$ \\
\hline
\end{tabular}

Different lowercase letters $(a, b, c)$ following data in each row of the table indicate significant difference among treatments at 0.05 level.

\subsection{Effects of a Mixture of Lime, Organic Fertilizer, and Porous Ceramics Nanomaterials on Soil Available Cd Content}

Available Cd content of the soil from the high-Cd area, low-Cd area, and non-Cd area in 2016 were presented in Table 2.

The available $\mathrm{Cd}$ content of the soil from the low-Cd area was lower than that from the high-Cd area (Table 2). The soil available $\mathrm{Cd}$ content was $0.26-0.41 \mathrm{mg} \cdot \mathrm{kg}^{-1}$ with an average of $0.36 \mathrm{mg} \cdot \mathrm{kg}^{-1}$ in the low-Cd area while it was $0.60-1.48 \mathrm{mg} \cdot \mathrm{kg}^{-1}$ (average of $1.04 \mathrm{mg} \cdot \mathrm{kg}^{-1}$ ) in the high-Cd area without using soil amendments. After application of lime, organic fertilizers and porous ceramics in the high-Cd area, soil available $C d$ content reduced to $0.24-1.22 \mathrm{mg} \cdot \mathrm{kg}^{-1}$ with an average of $0.74 \mathrm{mg} \cdot \mathrm{kg}^{-1}$. Soil amendments were able to reduce soil available $\mathrm{Cd}$ content by $1.1-75.8 \%$ with an average of $27.7 \%$. The reduction of available $\mathrm{Cd}$ content in soil was significant for rice varieties of Liangyou 8106, Zhenzhuai, Teqing, Fengliangyouxiang 1, Xinkedao 21, Yangjing 4227, Wandao 68, Zhendao 14, Jiayou 2, Xudao 7, Xudao 5, Xiushui 63, Zhendao 11, and Ninging 4. At the same time, the significant reduction of $\mathrm{Cd}$ content in rice grains was found for rice varieties of Liangyou 8106, Zhenzhuai, Teqing, Xinkedao 21, Yangjing 4227, Jiayou 2, Xudao 7, Xudao 5, Xiushui 63, and Zhendao 11.

\subsection{Effects of Lime, Organic Fertilizers, and Porous Ceramics on Rice Yields}

Rice yields from the high-Cd area, low-Cd area, and non-Cd area in 2016 were presented in Table 3.

Rice yields in the low-Cd area were significantly higher than those in the high-Cd area. Yields of the rice grown in the low-Cd area reached $10934-12384 \mathrm{~kg} \cdot \mathrm{hm}^{-2}$ with an average of $11697 \mathrm{~kg} \cdot \mathrm{hm}^{-2}$. In the High Cd area without using these amendments, rice yields were $7471-9778 \mathrm{~kg} \cdot \mathrm{hm}^{-2}$ with an average of $8699 \mathrm{~kg} \cdot \mathrm{hm}^{-2}$. High-yield rice varieties included Zhendao 11, Xudao 7, Jiayou 2, Xinliangyou 106, Liangyou 8106, and Xinkedao 21 with yields higher than $9100 \mathrm{~kg} \cdot \mathrm{hm}^{-2}$. At the same time, the rice varieties met the national food safety standard of grain $\mathrm{Cd}$ content included Jiayou 2, Xudao 7, and Zhendao 11. After using these amendments in the high-Cd area, rice yields increased to $7271-9370 \mathrm{~kg} \cdot \mathrm{hm}^{-2}$ with an average of $8516 \mathrm{~kg} \cdot \mathrm{hm}^{-2}$. The high-yield varieties included Xudao 7, Jiayou 2, Xinliangyou 106, Zhendao 11, Yangjing 4227, Liangyou 8106, and Teqing with yields higher than $8700 \mathrm{~kg} \cdot \mathrm{hm}^{-2}$. At the same time, grain Cd content of all rice varieties except Liangyou 8106 met the national food safety standard. After the application of the soil amendment, most of the rice varieties 
increased their yields but the increase was not significant. The rice yields of Jiayou 2 and Liangyou 766 were slightly reduced and the reduction was not significant. In general, the soil amendments did not have significant impacts on rice yields.

Table 3. Rice yields with different treatments.

\begin{tabular}{|c|c|c|c|c|}
\hline \multirow{2}{*}{\multicolumn{2}{|c|}{ Rice Variety }} & \multicolumn{3}{|c|}{ Rice Yields (kg.hm ${ }^{-2}$ ) } \\
\hline & & High-Cd Area & $\begin{array}{l}\text { High-Cd Area + } \\
\text { Soil Amendment }\end{array}$ & Low-Cd Area \\
\hline \multirow{8}{*}{ Indica rice variety } & Liangyou 8106 & $9520 \pm 24 a$ & $8967 \pm 17 a$ & $11339 \pm 32 b$ \\
\hline & Zhenzhuai & $8453 \pm 24 a$ & $8259 \pm 27 a$ & \\
\hline & Liangyou 766 & $8225 \pm 13 a$ & $7661 \pm 11 b$ & $11379 \pm 18 c$ \\
\hline & Teqing & $8685 \pm 23 a$ & $8759 \pm 23 a$ & $11772 \pm 35 b$ \\
\hline & Xinliangyou 106 & $9331 \pm 20 a$ & $9370 \pm 22 a$ & $12384 \pm 20 b$ \\
\hline & Liangyou 6206 & $8817 \pm 24 a$ & $8535 \pm 24 a$ & \\
\hline & Fengliangyouxiang 1 & $8841 \pm 5 a$ & $8850 \pm 12 a$ & $12169 \pm 10 b$ \\
\hline & Nanjing 11 & $8789 \pm 34 a$ & $8880 \pm 27 a$ & \\
\hline \multirow{11}{*}{ Japonic rice variety } & Xinkedao 21 & $8975 \pm 38 a$ & $8520 \pm 12 a$ & \\
\hline & Zhendao 18 & $8441 \pm 34 a$ & $8483 \pm 11 a$ & $12088 \pm 12 b$ \\
\hline & Yangjing 4227 & $8834 \pm 18 \mathrm{a}$ & $8891 \pm 6 a$ & $11474 \pm 23 b$ \\
\hline & Wandao 68 & $8730 \pm 35 a$ & $8667 \pm 13 a$ & \\
\hline & Zhendao 14 & $7694 \pm 14 a$ & $7661 \pm 21 a$ & \\
\hline & Jiayou 2 & $9778 \pm 28 a$ & $9004 \pm 11 b$ & \\
\hline & Xudao 7 & $9330 \pm 28 a$ & $9231 \pm 11 a$ & $12003 \pm 16 b$ \\
\hline & Xudao 5 & $7490 \pm 14 a$ & $7271 \pm 12 \mathrm{a}$ & $10934 \pm 10 b$ \\
\hline & Xiushui 63 & $8442 \pm 19 a$ & $8036 \pm 41 a$ & $11276 \pm 20 b$ \\
\hline & Zhendao 11 & $9165 \pm 31 a$ & $8849 \pm 13 a$ & \\
\hline & Ningjing 4 & $7471 \pm 28 \mathrm{a}$ & $7436 \pm 21 a$ & $11441 \pm 23 b$ \\
\hline
\end{tabular}

\section{Discussion}

\subsection{Criteria for Low Accumulation Rice Varieties}

Selection of low-cadmium rice varieties was the main strategy to prevent cadmium poisoning from entering the food chain and eventually entering humans. Plant growth, agronomic traits and low $\mathrm{Cd}$ uptake are major factors. Liu et al. proposed the following standards to evaluate low heavy metal accumulating varieties: a) The amount of heavy metal accumulated in plants should be low, or at least the contents in the edible parts must be lower than the national safety standards; b) Plants with a strong tolerance to heavy metals can grow as normal plants on heavy metal contaminated soil without significantly reducing biomass production; c) The transport of heavy metal to above-ground tissues is minimum. Heavy metals must be accumulated mainly in roots and the transportation index should be below 1.0; and d) Heavy metal contents in plants should be lower than the soil level and the enrichment index should be lower than 1.0 [17]. Based on the present study, we suggested the following criteria: the low metal accumulation in the edible parts should be persistent for at least three growth seasons.

The single contamination index was recommended by China Green Food Development Center. This method was also used in the analyses of heavy metal contamination [18]. The present study used the Secondary Standards in GB 15618-1995 Environmental Quality Standard for soil. The farmland had soil Pi value of $\mathrm{Cd}$ of $0.87,1.30$, and 6.1 , for non-contaminated, lightly contaminated, and heavily contaminated soil, respectively.

\subsection{Mechanisms of Low Accumulation of $C d$ in Crops}

The distribution of heavy metals in crops may be divided into four compartments, including chloroplasts and plastids, cell walls, soluble parts, and organelles [19]. The accumulation of heavy metals in plants is related to their physiological processes of absorption, transport, and detoxification. 
Crops such as rice can reduce the transport of heavy metals through several defense mechanisms including combination with cell walls, active efflux and through plasma membranes. Several metal detoxification mechanisms, such as chelating and metal thioredin detoxification, could also be used to reduce the accumulation of heavy metals and their toxicity to the crops [20]. Studies on rice, Arabidopsis, and other organisms showed that metal transporters, $A B C$ transporters, and natural resistance-associated macrophage protein transporters were involved in cadmium stress response. There were nine metal transporters found in rice. OsHMA9-OsHMA4 for the monovalent cations such as $\mathrm{Ag} / \mathrm{Cu}$; OsHMA3-OsHMA1 for the divalent cations including $\mathrm{Cd} / \mathrm{Co} / \mathrm{Zn} / \mathrm{Pb}$ [21]. The cell walls of crop roots are mainly composed of polysaccharides and proteins, which provide negative charge points on the surface and limit the transmembrane transport of metal ions. They are the first barrier to protect protoplast from metal toxicity [22]. Vacuoles occupy $90 \%$ of the cell volume [23] and contain abundant peptides and organic acids [24]. Vacuolar storage is the main process to limit the transfer of heavy metals in plants [20]. After accumulation of heavy metals, rice and other crops can still grow normally depending on detoxification mechanisms in crops, mainly through chelating metal ions with high affinity ligands [25]. Potential ligands for heavy metals include SH group peptides, such as plant chelating peptide (PC), glutathione (GSH) and small genes encode proteins rich in cysteine metallothionein (MT) [20]. Cai et al. reported that exogenously added reduced glutathione improved the cadmium tolerance of rice [26]. Hu et al. (2009), also showed that glutathione S-transferase and reduced glutathione in rice played an important role in cadmium passivation and detoxification [27]. The glutamine synthetase also participated in the detoxification of metal ions mediated by the plant chelating peptides [28].

\subsection{Cd Grain Accumulation among Different Rice Varieties}

Several previous studies revealed the differences in Cd uptake and accumulation among rice genotypes, which could be determined by genes $(G)$, environmental factors (E), or their interactions $[29,30]$. Studies also showed that the cadmium content of seven rice types was in the order of Xenopus laevis, conventional japonica rice, conventional late japonica rice, two-line late rice, three-line late rice, conventional early Indica, and special rice [31]. However, $\mathrm{Xu}$ et al. reported that $\mathrm{Cd}$ contents of polished rice differed among various varieties, which could not be distinguished between hybrids and conventional rice in general [15]. A large-scale survey of 20 provinces in the four rice growing regions in China indicated that $\mathrm{Cd}$ content in 712 samples of rice varied from $<0.001$ to $0.74 \mathrm{mg} \cdot \mathrm{kg}^{-1}$ [32]. They also showed that there were significant genetic variations in $\mathrm{Cd}$ accumulation capacity of the 45 rice varieties. Conventional Japonica and Indica rice varieties of these 45 rice cultivars accumulated less $\mathrm{Cd}$ than hybrid ones, which was in agreement with the previous study. It has been reported that $\mathrm{Cd}$ accumulation capacity of brown rice decreased in the order of Indica hybrids> Japonica hybrids $>$ conventional Indica rice $>$ conventional Japonica rice [33]. In present study, there was also significant variation in $\mathrm{Cd}$ accumulation capacity among rice varieties. Conventional varieties accumulated less $\mathrm{Cd}$ than hybrid varieties in high-Cd area. Therefore, screened rice varieties may be safely produced in Cd lightly polluted soil.

\subsection{Effects of Cd on Crop Growth and Development}

Several studies reported that heavy metals in plants, when reaching to a threshold level, became toxic to plants causing disruption in metabolic pathways, slowed crop growth and lowered yields by the following mechanisms [34]. Cd causes DNA damage in rice. $\mathrm{Cd}^{2+}$ can cause abnormal DNA methylation, which affects gene viability, interferes with the synthesis of enzymes and proteins, and fundamentally causes damage to crop growth and development [35]. Low concentration of $\mathrm{Cd}^{2+}$ promoted the respiration rate of rice leaves. However, higher concentrations of $\mathrm{Cd}^{2+}$ can cause a significant decrease in the content of Photosystem II, Photosystem I and light-harvesting pigment-protein complexes in leaves, thereby inhibiting the photosynthetic rate. In addition, $\mathrm{Cd}^{2+}$ can also inhibit the mutual transformation of photosynthetic products in leaves, interfere with the 
output of leaf photosynthetic products and inhibit the input of photosynthetic products, resulting in the accumulation of small molecules of sugar in the leaves, which leads to the feedback inhibition of photosynthesis. $\mathrm{Cd}^{2+}$ can cause a decrease in the water-soluble protein content of rice roots and leaves, leading to inhibition of protein hydrolysis and synthesis. $\mathrm{Cd}^{2+}$ can also inhibit amylase and MDH activity and isozyme expression in various organs, preventing the tricarboxylic acid cycle [36,37].

The present study showed that there were some differences in yields among rice varieties. Rice $\mathrm{Cd}$ content had a significant negative correlation with yields. Grain yields in the low-Cd area were significantly higher than that in the high-Cd area.

\subsection{Effect of Soil Amendment on the Accumulation of $\mathrm{Cd}$ in Crops}

Organic matters have large specific surface area and a large number of functional groups. Humic acids could form a chelate complex with soil $\mathrm{Cd}$. These interactions reduced the mobility of $\mathrm{Cd}$ and thus reduce its uptake into plants [38]. A large number of studies showed that organic fertilizers effectively increased crop yields [39,40]. Zhao et al. and Li et al. reported that when organic fertilizers were used in place of inorganic fertilizers, rice yields increased significantly [41,42].

The characteristics of the porous ceramic nanomaterials included high molecular recognition capability, sand particle structure, and optimized slow release. These materials were extremely effective in soil remediation against heavy metal contamination. The field experiments in Hunan Province of China showed that, after using these soil amendment in rice fields, water soluble $\mathrm{Cd}$ in soils was reduced from $322 \mathrm{ppb}$ to $0.89 \mathrm{ppb}$ resulting in a $99 \%$ absorption rate. The elimination rate of soil available $\mathrm{Cd}$ was $85 \%$. The porous ceramics nanomaterials were applied in rice fields resulting in a $61 \%$ reduction in soil Cd content [13]. Lime also changed soil CEC, soil $\mathrm{pH}$, soil redox status, and soil microbial communities. All of these factors affected soil capacity in chelation, precipitation, and adsorption of heavy metals $[43,44]$.

Several studies indicated that soil available Cd content had a significant negative correlation with soil $\mathrm{pH}$. Soil $\mathrm{pH}$ increased after amendment with lime, which reduced soil available $\mathrm{Cd}$ content and then less Cd uptake into plants [45]. Gu et al. reported that limes, when combined with other soil amendments were more effective than it was used alone in soil remediation [46]. Other studies confirmed that lime and $\mathrm{Ca}$ compounds were able to bind up to $95-99 \%$ of $\mathrm{Cd}, \mathrm{Pb}, \mathrm{Cr}$, and $\mathrm{As}$ and other heavy metals $[47,48]$.

In the present study, the application of lime, organic fertilizer, and porous ceramic nanomaterials as soil amendments in the high-Cd area was able to reduce the soil available $\mathrm{Cd}$ content and the $\mathrm{Cd}$ content in rice grain with little effects on rice yields. The cadmium content of grains met the national food safety standards and guaranteed the safe consumption of rice. This integrated remediation approach proved effective in improving remediation efficiency. However, the dosage and the types of soil amendment should be determined according to the species of heavy metals, the level of contamination, and type of soil.

\section{Conclusions}

There was significant variation in $\mathrm{Cd}$ accumulation capacity among rice varieties. In the non-Cd area, $\mathrm{Cd}$ content in all rice grains reached the national food safety standard. In the high-Cd area conventional varieties accumulated less $C d$ than hybrid varieties. The following 19 rice varieties (Ningjing 4, Zhendao 11, Xiushui 63, Xudao 5, Xudao 7, Jiayou 2, Zhendao 14, Wandao 68, Yangjing 4227, Zhendao 18, Nanjing 11, Fengliangyouxiang 1, Liangyou 6206, Xinliangyou 106, Xinkedao 21, Teqing, Liangyou 766, Zhenzhuai, Liangyou 8106) showed the characteristics of low accumulation of cadmium. Among them, five varieties exhibited high yields and low $\mathrm{Cd}$ accumulating traits: Zhenzhuai, Liangyou 766, Xinkedao 21, Ningjing 4, and Xinliangyou 106. There was no significant difference in yields among rice varieties. $\mathrm{Cd}$ content in rice grains had a significant negative correlation with yields. 
Application of lime, organic fertilizer, and porous ceramic nanomaterials as soil amendments in the high-Cd area was able to reduce the soil available $\mathrm{Cd}$ content and the $\mathrm{Cd}$ content in rice grains with little effect on rice yields. The low-Cd accumulating varieties selected in this study were all within the national grain safety standard in the $\mathrm{Cd}$ lightly contaminated fields. In the high-Cd area without soil amendments, rice Cd content of six varieties (Ningjing 4, Zhendao 11, Xiushui 63, Xudao 5 , Xudao 7, Jiayou 2) were within the national grain safety standard limits. After the application of soil amendements, the following 13 varieties rice were able to meet the national grain safety standard (Ningjing 4, Zhendao 11, Xiushui 63, Xudao 5, Xudao 7, Jiayou 2, Zhendao 14, Wandao 68, Yangjing 4227, Zhendao 18, Xinliangyou 106, Xinkedao 21, Teqing). Therefore, the current study implies that proper agronomic management with selection of rice varieties and soil amendments is essential in controlling $\mathrm{Cd}$ accumulation in rice grains.

Author Contributions: Methodology, Y.M., L.C., and W.W.; Experiment, L.M., H.F., J.L., and W.Y.; Formal analysis, L.C.; Data curation, L.C. and Y.Y.; Writing-original draft preparation, L.C.; Writing-review and editing, Y.M., F.H., and Q.W.; Funding acquisition, Y.M., J.L., and W.Y.

Funding: The research was funded by National Natural Science Foundation Project (41301539); Agricultural Ecological Environment Protection Major Special Project of the Ministry of Agriculture (Agricultural Ecological Environment Protection Major Special Project of the Ministry of Agriculture [2012] 3); Key projects of the Department of Education of Anhui Province (2014 revitalization plan 03090304).

Conflicts of Interest: The authors declare no conflict of interest.

\section{References}

1. Wang, X.C.; Yan, W.D.; An, Z.; Liu, Q.; Shi, W.M.; Cao, Z.H.; Wong, M.H. Status of trace elements in paddy soil and sediment in Taihu Lake region. Chemosphere 2003, 50, 707-710. [CrossRef]

2. Chaney, R.L.; Reeves, P.G.; Ryan, J.A.; Simmons, R.W.; Welch, R.M.; Scott Angle, J. An improved understanding of soil $\mathrm{Cd}$ risk to humans and low cost methods to phytoextract $\mathrm{Cd}$ from contaminated soils to prevent soil Cd risks. Biometals 2004, 17, 549-553. [CrossRef] [PubMed]

3. Penner, G.A.; Bezte, L.J.; Leisle, D.; Clarke, J. Identification of PAPD markers linked to a gene governing cadmium uptake in durum wheat. Genome 1995, 38, 543-547. [CrossRef] [PubMed]

4. Li, Y.M.; Channey, L.R.; Schneiter, A.A. Genotypic variation in kernel cadmium concentration in sunflower germplasm under varying soil conditions. Crop Sci. 1995, 35, 137-141. [CrossRef]

5. Liu, J.G.; Li, K.Q.; Xu, J.K.; Liang, J.S.; Lu, X.L.; Yang, J.C.; Zhu, Q.S. Interaction of Cd and five mineral nutrients for uptake and accumulation in different rice cultivars and genotypes. Field Crops Res. 2003, 83, 271-281. [CrossRef]

6. Shi, J.; Li, L.; Pan, G. Variation of grain Cd and Zn concentrations of 110 hybrid rice cultivars grown in a low-Cd paddy soil. J. Environ. Sci. 2009, 21, 168-172. [CrossRef]

7. Yu, H.; Wang, J.W.; Fang, W.; Yuan, J.G.; Yang, Z.Y. Cadmium accumulation in different rice cultivars and screening for pollution-safe cultivars of rice. Sci. Total Environ. 2006, 370, 302-309. [CrossRef]

8. Ishikawa, S.; Ae, N.; Sugiyama, M.; Murakami, M.; Arao, T. Genotypic variation in shoot cadmium concentration in rice and soybean in soils with different levels of cadmium contamination. Soil Sci. Plant Nutr. 2005, 51, 101-108. [CrossRef]

9. Ke, Q.M.; Liang, K.J.; Zhu, Y.; Xiao, M.X.; Lin, W.X. Interactive effect of genotype and environment on the genetic covariance of characterization of heavymetal accumulation in ediblerice grain (Oryza sativa L.). Chin. J. Eco-Agric. 2006, 14, $24-27$.

10. Ma, T.Z.; Ma, Y.H.; Xu, L.L.; Fu, H.H.; Nie, J.R. Agro-ecological Remediation Technologies on Heavy Metal Contamination in Cropland Soils. J. Agric. Resour. Environ. 2013, 30, $39-43$.

11. Zhan, S.J.; Yu, H.; Feng, W.Q.; Qin, Y.S.; Liao, M.L.; Wang, C.Q.; Tu, S.H. Effects of different organic material and lime on wheat grow and cadmium uptake. J. Soil Water Conserv. 2011, 25, 214-217.

12. Lahori, A.H.; Zhang, Z.Q.; Guo, Z.Y.; Mahar, M.; Li, R.H.; Awasthi, M.K.; Sial, T.A.; Kumbhar, F.; Wang, P.; Shen, F.; et al. Potential use of lime combined with additives on (im)mobilization and phytoavailability of heavy metals from Pb/Zn smelter contaminated soils. Ecotoxicol. Environ. Saf. 2017, 145, 313-323. [CrossRef] [PubMed] 
13. Chen, L.M.; Ma, Y.H.; Wang, C.S.S.; Li, J.X.; Ye, W.L.; Wu, L.C.; Cui, J.Y. Remediation Technology Against Heavy Metal Pollution in Farmland Soil with Different Pollution Levels. Chin. Agric. Sci. Bull. 2016, 32, 94-99.

14. Murakami, M.; Ae, N.; Ishikawa, S. Phytoextraction of cadmium by rice (Oryza Sativa, L.), soybean (Glycine $\max ($ L.) Merr.), and maize (ZeaMays, L.). Environ. Pollut. 2007, 145, 96-103. [CrossRef] [PubMed]

15. Xu, Y.L.; Chen, N.C.; Xu, S.G.; Zhou, J.M.; Xie, Z.Y.; Li, Z.A. Breeding Rice Cultivars with Low Accumulation of Cadmium: Cultivars Versus Types. J. Agro-Environ. Sci. 2009, 28, 1346-1352.

16. Bai, X.Y.; Yuan, F.; Li, X.L.; Zhou, T.F.; Zhang, X.; Chen, X.R.; Chen, Y.N.; Chen, F.R.; Jia, S.J. Spatial variance and pollution analysis of soil heavy metals in Tongling mining area, South China. Earth Sci. Front. 2008, 15, 256-263.

17. Liu, W.T.; Zhou, Q.X.; Sun, Y.B.; Yu, Z.G. Genotypic Variation of Cadmium Accumulation in Chinese cabbage (BrassicapekinensisL). J. Basicsci. Eng. 2010, 18, 226-236.

18. Li, X.; Jiang, X.X.; Gao, H.J. Pollutiion assesssment and source analysis of soil heavy mental in Taihulake Basin. Trans. Chin. Soc. Agric. Mach. 2017, 11, 247-253.

19. Wu, F.; Dong, J.; Qian, Q.; Zhang, G. Subcellular distribution and chemical form of Cd and Cd-Zn interaction in different barley genotypes. Chemosphere 2005, 60, 1437-1446. [CrossRef]

20. Chen, L.M.; Li, J.X.; Hu, Z.Y.; Ye, W.L.; Wu, W.G.; Ma, Y.H. Review on Application of Low Accumulation Crops on Remediation of Farmland Contaminated by Heavy Metals. Crops 2018, 1, 16-24.

21. Williams, L.E.; Mills, R.F. P(1B)-ATPases-an ancient family of transition metal pumps with diverse functions in plants. Trends Plant Sci. 2005, 10, 491-502. [CrossRef] [PubMed]

22. Fu, X.P.; Dou, C.M.; Chen, Y.X.; Chen, X.C.; Shi, J.Y.; Yu, M.G.; Xu, J. Subcellular distribution and chemical forms of cadmium in Phytolacca americana L. J. Hazard. Mater. 2011, 186, 103-107. [CrossRef] [PubMed]

23. Pittman, J.K. Managing the manganese: Molecular mechanisms of manganese transport and homeostasis. New Phytol. 2005, 167, 733-742. [CrossRef] [PubMed]

24. Weigel, H.J.; Jäger, H.J. Subcellular distribution and chemical form of cadmium in bean plants. Plant Physiol. 1980, 65, 480-482. [CrossRef] [PubMed]

25. Ishikawa, S.; Suzui, N.; Ito-Tanabata, S.; Ishii, S.; Igura, M.; Abe, T.; Kuramata, M.; Kawachi, N.; Fujimaki, S. Real-time imaging and analysis of differences in cadmium dynamics in rice cultivars(Oryza sativa) using position-emitting $107 \mathrm{Cd}$ tracer. BMC Plant Biol. 2011, 11, 1-12. [CrossRef] [PubMed]

26. Cai, Y. Differences in Genotypes of Cadmium Tolerance in Rice and Mechanisms of Exogenous GSH to Alleviate Cadmium Toxicity; Zhejiang University: Hangzhou, China, 2010.

27. Hu, Y.L.; Zhang, C.H.; Ju, T.; Ge, Y. Differential responses of GSH and GST in two rice cultivars under Cd stress. J. Ago-Environ. Sci. 2009, 28, 305-310.

28. Hossain, Z.; Hajika, M.; Komatsu, S. Comparative proteome analysis of high and low cadmium accumulating soybeans under cadmium stress. Amino Acids 2012, 6, 2393-2416. [CrossRef]

29. Li, W.L.; Xu, B.B.; Song, Q.J.; Liu, X.M.; Xu, J.M.; Brookes, P.C. The identification of 'hotspots' of heavy metal pollution in soil-rice systems at a regional scale in eastern China. Sci. Total Environ. 2014, 472, 407-420. [CrossRef]

30. Hseu, Z.-Y.; Su, S.-W.; Lai, H.-Y.; Guo, H.-Y.; Chen, T.-C.; Chen, Z.-S. Remediation techniques and heavy metal uptake by different rice varieties in metal-contaminated soils of Taiwan: New aspects for food safety regulation and sustainable agriculture. Soil Sci. Plant Nutr. 2010, 56, 31-52. [CrossRef]

31. Zeng, X.; Zhang, Y.Z.; Wang, K.R.; Zhou, L.J.; Zhang, Y.P.; Xie, J.H.; Tu, N.M. Genotype difference of brown rices in Cd content. J. Ecol. Rural Environ. 2006, 22, 67-69.

32. Qian, Y.; Chen, C.; Zhang, Q.; Li, Y.; Chen, Z.; Li, M. Concentrations of cadmium, lead, mercury and arsenic in Chinese market milled rice and associated population health risk. Food Control 2010, 21, 1757-1763. [CrossRef]

33. Xie, L.H.; Tang, S.Q.; Wei, X.J.; Shao, J.N.; Jiao, G.A.; Sheng, Z.H.; Luo, J.; Hu, P.S. The cadmium and lead content of the grain produced by leading Chinese rice cultivars. Food Chem. 2017, 217, 217-224. [CrossRef] [PubMed]

34. He, Y.B.; Huang, D.Y.; Zhu, Q.H.; Wang, S.L.; Shou, L.; He, H.B.; Zhu, H.H.; Xu, C. A three-season field study on the in-situ remediation of Cd-contaminated paddy soil using lime, two industrial by-products, and a low-Cd-accumulation rice cultivar. Ecotoxicol. Environ. Saf. 2017, 136, 135-141. 
35. Huang, B.F.; Xin, J.L.; Dai, H.W.; Zhou, W.J. Effects of interaction between cadmium (Cd) and selenium (Se) on grain yield and Cd and Se accumulation in a hybrid rice (Oryza sativa) system. J. Agric. Food Chem. 2017, 25, 9537-9546. [CrossRef] [PubMed]

36. Liu, J.G.; Cai, G.L.; Qian, M.; Wang, D.K.; Xu, J.K.; Yang, J.C.; Zhu, Q.S. Effect of Cd on the growth, dry matter accumulation and grain yield of different rice cultivars. J. Sci. Food Agric. 2007, 87, 1088-1095. [CrossRef]

37. Ge, C.L. Molecular Mechanism of Heavy Metal Toxicity and Tolerance in Rice (Oryza sativa L.) and Wheat (Triticum Aestivum, L.); Zhejiang University: Hangzhou, China, 2002.

38. Ding, J.H.; Wen, Y.M.; Shu, Q. Fraction transformation of cadmium and zinc in soils. Urban Environ. Urban Ecol. 2001, 14, 47-49.

39. Yang, J.; Gao, W.; Ren, S.R. Long-term effects of combined application of chemical nitrogen with organic materials on crop yields, soil organic carbon and total nitrogen in fluvo-aquic soil. Soil Tillage Res. 2015, 151, 67-74. [CrossRef]

40. Ma, Y.H.; Gu, D.J.; Liu, L.J.; Wang, Z.Q.; Zhang, H.; Yang, J.C. Changes in grain yield of rice and emission of greenhouse gases from paddy fields after application of organic fertilizers made from maize straw. Rice Sci. 2014, 21, 224-232. [CrossRef]

41. Zhao, J.; Ni, T.; Li, J.; Lu, Q.; Fang, Z.Y.; Huang, Q.W.; Zhang, R.F.; Li, R.; Shen, B. Effects of organic-inorganic compound fertilizer with reduced chemical fertilizer application on crop yields, soil biological activity and bacterial community structure in a rice -wheat cropping system. Appl. Soil Ecol. 2016, 99, 1-12. [CrossRef]

42. Li, X.; Liu, Q.; Rong, X.M.; Xie, G.X.; Zhang, Y.P.; Peng, J.W.; Song, H.X. Effects of organic fertilizers on yield and quality of rice grains and nitrogen use efficiency. J. Hunan Agric. Univ. 2010, 36, 258-262. [CrossRef]

43. Chen, Y.Q.; Zhang, Y.; Chen, G.L. Remediation of Heavy Metal Contaminated Soils by Lime: A Review. Ecol. Environ. Sci. 2016, 25, 1419-1424.

44. Bolan, N.S.; Adriano, D.C.; Mani, P.A.; Duraisamy, A. Immobilization and phytoavailability of cadmium in variable charge soils II. Effect of lime addition. Plant Soil 2003, 251, 187-198. [CrossRef]

45. Bie, R.S.; Chen, P.; Song, X.F. Characteristics of municipal solid waste incineration fly ash with cement solidification treatment. J. Energy Inst. 2016, 89, 704-712. [CrossRef]

46. Gu, Q.N.; Jin, H.L.; Zhou, L. Experimental Research on Passivator Used in Soil Heavy Metal Pollution Repair. Energy Energy Conserv. 2015, 11, 105-106.

47. Mallampati, S.R.; Mitoma, Y.; Okuda, T.; Sakita, S.; Kakeda, M. Enhanced heavy metal immobilization in soil by grinding with addition of nanometallic $\mathrm{Ca} / \mathrm{CaO}$ dispersion mixture. Chemosphere 2012, 89, 717-723. [CrossRef] [PubMed]

48. Mallampati, S.R.; Mitoma, Y.; Okuda, T.; Sakita, S.; Simion, C. Simultaneous decontamin- ation of cross-polluted soils with heavy metals and PCBs using a nano-metallic $\mathrm{Ca} / \mathrm{Cao}$ dispersion mixture. Environ. Sci. Pollut. Res. 2014, 21, 9270-9277. [CrossRef] [PubMed]

(C) 2019 by the authors. Licensee MDPI, Basel, Switzerland. This article is an open access article distributed under the terms and conditions of the Creative Commons Attribution (CC BY) license (http://creativecommons.org/licenses/by/4.0/). 